Original article

Received: 2 November 2016 / Accepted: 10 March 2017

\title{
INTEGRATED PRECIPITABLE WATER FROM GPS OBSERVATIONS AND CIMEL SUNPHOTOMETER MEASUREMENTS AT CGO BELSK
}

\author{
Michał Kruczyk ${ }^{1}$, Tomasz Liwosz ${ }^{1}$, Aleksander Pietruczuk ${ }^{2}$ \\ 1) Faculty of Geodesy and Cartography, Warsaw University of Technology, \\ Department of Geodesy and Geodetic Astronomy \\ 2) Institute of Geophysics, Polish Academy of Sciences
}

\begin{abstract}
This paper describes results of integrated precipitable water co-located measurements from two techniques: GPS solution and CIMEL-318 sunphotometer. Integrated Precipitable Water (IPW) is an important meteorological parameter and is derived from GPS tropospheric solutions for GPS station at Central Geophysical Observatory (CGO), Polish Academy of Sciences (PAS), Belsk and compared with sunphotometer (CIMEL-318 device by Cimel Electronique) data provided by Aerosol Robotic Network (AERONET). Two dedicated and independent GPS solutions: network solution in the sub-network of European Permanent Network (EPN) and precise point positioning solution have been made to obtain tropospheric delays. The quality of dedicated tropospheric solutions has been verified by comparison with EPN tropospheric combined product. Several IPW comparisons and analyses revealed systematic difference between techniques (difference RMS is over $1 \mathrm{~mm}$ ). IPW bias changes with season: annual close to $1 \mathrm{~mm} I P W$ (and semi-annual term also present). IPW bias is a function of atmospheric temperature. Probable cause of this systematic deficiency in solar photometry as IPW retrieval technique is a change of optical filter characteristics in CIMEL.
\end{abstract}

Keywords: water vapour, GPS, IPW, tropospheric delay, sunphotometer

\section{Introduction}

Water vapour is an extremely important component of water cycle and plays a crucial role in many meteorological, climatologic and environmental processes (such as evapotranspiration, condensation, precipitation, thermodynamics - latent heat release, cloudiness and its impact on insolation, etc.) as acknowledged in numerous sources even at the textbook level (e.g. Shelton, 2009; Mcllven, 2010; Salby, 2012). Average value of IPW (often named simply precipitable water - PW) for the Earth is about $25 \mathrm{~mm}$ but average precipitation amounts to about $1000 \mathrm{~mm}$ which exhibits 
clear evidence of high dynamics of hydrological processes (45 evaporationcondensation cycles in one year). Water vapour contributes to a greenhouse gas effect more than carbon dioxide (but of course lasts in the atmosphere for a short time). In warmer atmosphere saturation water vapour pressure is higher and likewise water vapour density for the same relative humidity. Water vapour is both climate change agent and indicator (see e.g. Kruczyk, 2014). Integrated precipitable water, i.e. column water content in the whole of the atmosphere, provides the convenient measure of water vapour and is obtained by means of measurements by a variety of techniques.

There are several different techniques to observe/measure water vapour content in the atmosphere:

- in-situ meteorological measurements (various hygrometers, termohygrometers, capacity sensors etc.),

- radiosonde/dropsonde (direct measurements from the device moving through the atmosphere),

- Water Vapour Radiometry (WVR) - remote sensing possible both from ground and satellite platforms,

- LIDAR (especially Raman and DIAL types),

- Fourier Transform Infrared Spectrometry (FTIR),

- sun photometry (with rare lunar variety),

- differential optical absorption spectrometry (DOAS),

- GNSS meteorology (in detail described below).

Central to the paper is Chapter 5 - it describes results of observational campaign at CGO Belsk aimed at GPS CIMEL co-location. Results from network and PPP solution are described separately and critically summed up. Chapter 2 gives basics of GNSS meteorology and chapter 3 describes CIMEL sun photometer. Chapter 4 deals with GPS solutions minutes and their quality check. Chapter 6 presents conclusions. Most of the results presented here have been already published as a part of monograph in Polish (Kruczyk, 2013). Aim of the article is to make them available to English speaking science public. See also similar research by the authors concerning polar areas (Kruczyk \& Liwosz, 2015; Kruczyk, 2015).

\section{Basics of GNSS meteorology}

Atmospheric refraction of Global Positioning System (GPS) L-band navigational signal manifests itself in the form of tropospheric delay. For GPS measurement taken between a satellite at zenith and a receiver located at sea level, the zenith tropospheric delay (ZTD), in units of length, amounts to approximately $2.3 \mathrm{~m}$. The ZTDs need to be properly taken into account if high accuracy of station coordinates is needed, i.e., at the level of several millimetres. Valuable geodetic coordinate solutions for antenna phase centre should be below centimetre level (daily solutions). Due to limited accuracy of existing ZTD models, the most precise applications of GPS (geodynamics, geodetic reference frames) require the estimation of ZTDs during the adjustment of GPS observations, together with other parameters, e.g., station coordinates, phase ambiguities. Because of troposphere is correlated to the height component we need to deal with the tropospheric delay at the level of several millimetres. So called mapping functions required for computing tropospheric delay in any other direction than the zenith undergo especially impressive development in the recent years (the most advanced and suggested as IERS 2010 standard being 
Vienna Mapping Function VMF1). Because of temporal variability of troposphere and the estimation procedure implemented in the software, ZTDs are usually estimated every one hour for each station (e.g., 24 parameters for daily sessions) in case of least square method used in Bernese. In case of Kalman filter utilised in GIPSY estimation rate is $5 \mathrm{~min}$. Both in Bernese and GIPSY we obtain ZTD formal accuracy level of several millimetres. So the best way to eliminate tropospheric delay in GPS solutions is by the proper construction and solution of the observational equation system and the tropospheric delay is estimated stochastically together with coordinates (e.g. Hofman-Wellenhof B., 2008; chapter 5.3). In case of permanent GPS stations (maintained for most precise scientific solutions) there are two approaches to troposphere. The first is the noise-like treatment of ZTDs in geodetic applications. The second is the basis for GPS meteorology: GPS derived ZTDs are used for the purposes of atmospheric research (Duan et al., 1996). ZTD is a sum of zenith wet delay (ZWD) and zenith hydrostatic delay (ZHD). Zenith wet delay (ZWD), which is about $10 \%$ of ZTD, depends mostly on the content of water vapour along the path of signal propagation and is highly variable both spatially and temporally. ZHD depends mostly on surface atmospheric pressure, and can be computed at the several millimetres accuracy level from existing ZHD models using surface meteorological data. In this work Saastamoinen formula (Saastamoinen, 1972) with gravitational correction is used.

Integrated precipitable water (IPW) - i.e. total column of water vapour (as liquid), sometimes called columnar water vapour is derived from ZTD solution by universally accepted procedure involving first the separation of Wet Delay by calculation of Hydrostatic Delay:

$$
Z W D=Z T D-Z H D
$$

For $Z H D$ we use most frequently used Saastamoinen formula:

$$
Z H D=(2.2779) p / f(\varphi, H)
$$

Where $p$ is atmospheric pressure. Function $f(\varphi, H)$ reproduces changes of the force of gravity with latitude $\varphi$ and ellipsoidal station height $H$ in kilometres (Davis et al. 1985):

$$
f(\varphi, H)=(1-0.00266 \cos 2 \varphi-0.00028 H)
$$

Next we recalculate obtained ZWD by coefficient $k$ dependent on so called 'mean temperature' in vertical profile of atmosphere (Bevis et al. 1994, Rocken at al. 1993).

Where coefficient $K$ :

$$
I P W \approx \kappa \cdot Z W D
$$

$$
\frac{1}{\kappa}=10^{-6}\left(\frac{C_{3}}{T_{m}}+C_{2}^{\prime}\right) R_{V}
$$

Coefficient $\kappa$ has the value of about $1 / 6.4 ; R_{v}$ - is a specific gas constant for water vapour, $T_{m}$ - 'mean temperature', $C_{i}$ are empirical coefficients of air refractivity (given e.g. in Davis et al. 1985).

Mean temperature depends on the temperature vertical profile in the atmosphere (Bevis et al., 1994): 


$$
T_{m}=\frac{\int_{s}\left(P_{v} / T\right) \cdot d s}{\int_{s}\left(P_{v} / T^{2}\right) \cdot d s} \approx \frac{\int_{h_{0}}^{\infty}\left(P_{v} / T\right) \cdot d h}{\int_{h_{0}}^{\infty}\left(P_{v} / T^{2}\right) \cdot d h}
$$

We can approximate the mean temperature as linear function of surface temperature. Coefficient $\mathrm{K}$ depends on temperature profile but can be estimated by means of surface temperature at the GNSS station (Bevis et al., 1992):

$$
T_{m} \approx 70.2+0.72 \cdot T_{s}[\mathrm{~K}]
$$

It is an average formula for mean temperature obtained from 8718 radiosunding profiles in the US for latitudes: $27^{\circ}-65^{\circ} \mathrm{N}$. For central Poland radiosoundings are performed twice a day at Legionowo (WMO station number: 12374, latitude $52.40 \mathrm{~N}$, longitude $20.96 \mathrm{E}$, base elevation: $96.0 \mathrm{~m}$ ); about $64 \mathrm{~km}$ from Belsk. Linear formula for mean temperature obtained at Legionowo (for the period of 2012-2014) and further used for Belsk is only slightly different from equation (7):

$$
T_{m}=82.6+0.67 \cdot T_{s} \pm 4.5[\mathrm{~K}]
$$

It is also possible to calculate $T_{m}$ from numerical weather prediction model. For example: mean temperature is available at Technical University of Vienna (for www see References) where they are computed from ECMWF operational analysis pressure level data.

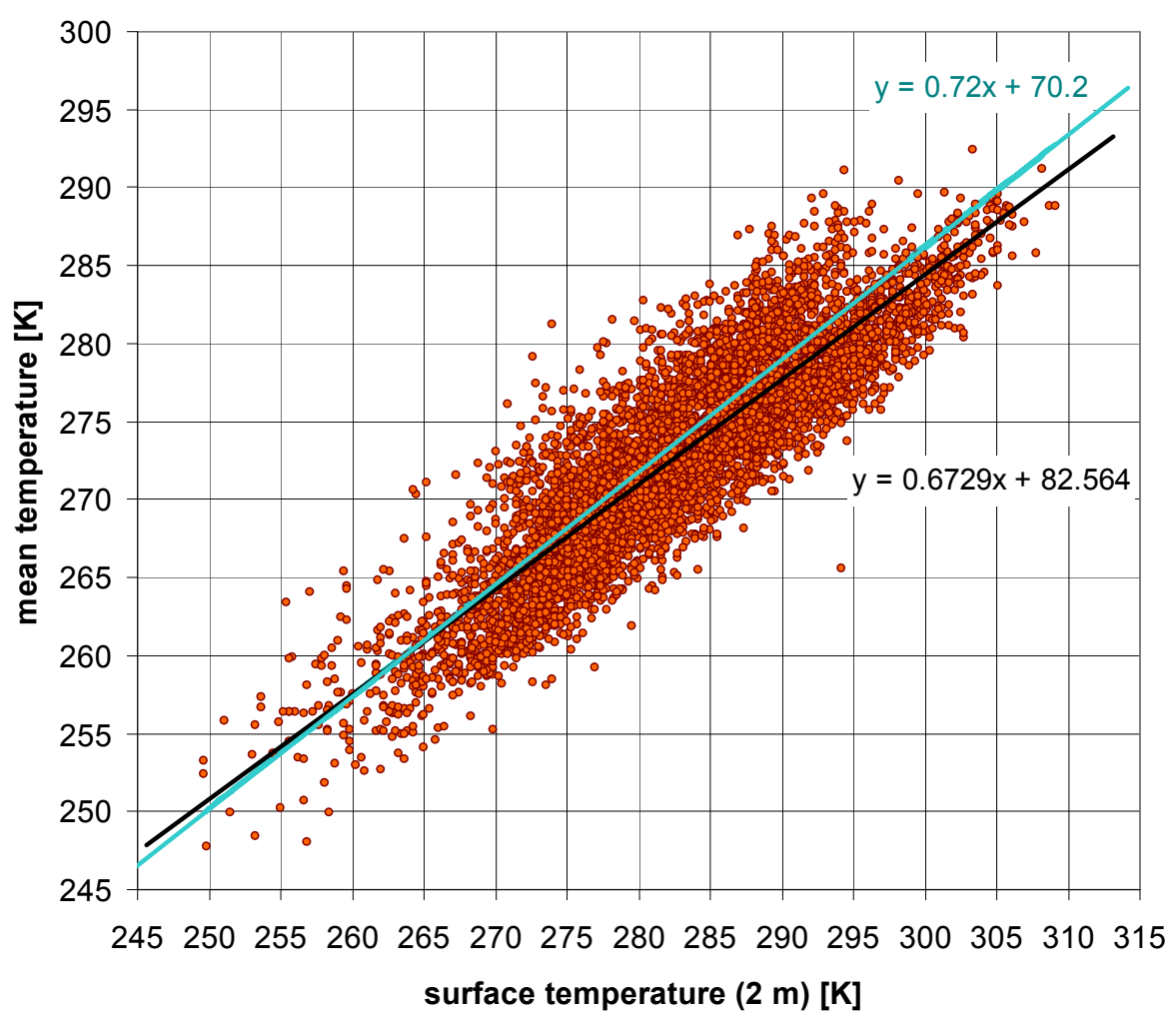

Fig. 1. Mean temperature vs. surface temperature for Legionowo, 2012-2014 (5811 soundings), linear formula fitting (black line) and Bevis formula (in blue). Note: visually the blue line seems to better fit the data because more point are superimposed in the lower part. 
A number of studies have shown that IPW estimates from ground-based GPS observations and meteorological/aerologic data give the same level of accuracy as radiosondes and microwave radiometers (see e.g. Vedel et al., 2001). GNSS meteorology is so a dynamic and abundant field that it takes full publication (or rather a book) to present the state of the art (see e.g. Böhm \& Schuh, 2013). Main aim of the paper is to test in comparison to standard GPS meteorology another water vapour data source - sun photometer.

\section{CIMEL sun photometer and AERONET network}

CIMEL-318 sun photometer is an important tool in aerosol research (Holben et al., 1998, Holben et al., 2001, Halthorne et al., 1997). CIMEL is an automatic/robotic sun tracking photometer (solar powered) produced by CIMEL Electronique (www.cimel.fr). These multifunctional devices are operated in the frame of AERONET (AErosol RObotic NETwork) program coordinated by NASA \& CNRS (www.aeronet.net). The globally distributed network of over 100 sites provides assured aerosol optical properties to monitor atmosphere, environment and validate remote sensing satellites retrievals. Sun photometer is a multi-channel radiometer which measures many air properties (mostly aerosoles) registering absorption of 8 line bands of solar spectrum $(340,380,440,500,675,870,940$ and $1020 \mathrm{~nm}$ nominal wavelengths; potentially also $1640 \mathrm{~nm}$ ). The automatic Sun and sky scanning radiometers make direct Sun measurements with a $1.2^{\circ}$ full FOV (field of view) at every $15 \mathrm{~min}$. The direct sun measurements take 8 seconds to scan all 8 wavelengths, with a motor driven filter wheel positioning each filter in front of the detector resulting in 3 measurements at each wavelength within a one minute period. These solar extinction measurements are then used to compute aerosol optical depth at each channel by means of comparing measurements of sky radiance with off-band wavelengths (with no absorption). CIMEL gives also IPW values (precisely - slant values in the direction to the Sun). The bandpass of ion assisted deposition interference filters (spectral windows breadth: FWHM - full width at half maximum) of most channels is $10 \mathrm{~nm}$ and include many individual lines of water vapour molecular spectral transitions (vibrational-rotational). Water vapour channels used by CIMEL are centered on $940 \mathrm{~nm}$ and $1020 \mathrm{~nm}$ (940 nm channel used solely to retrieve precipitable water). Radiometric/photometric technique has been also successfully applied to lunar light (Querel \& Naylor, 2011). The relationship used to estimate the PW from the water vapour transmittance $T_{w v}$ is:

$$
T_{w v}=e^{-a \cdot(m \cdot I P W)^{b}}
$$

The two constants $a$ and $b$ are related to the used water vapour channel and $m$ is the relative optical airmass:

$$
m=\frac{\int \rho \cdot d s}{\int \rho \cdot d z}
$$

where $s$ is the slant path of the solar ray, $z$ is the vertical path. 
Spectrometric detection and measurements of water vapour (in this case called CWV - column water vapour) is a demanding task because of the complexity of instrument's calibration (e. g. Schmid et al., 2001). CIMEL instruments use parameters (e.g. zero airmass voltages) from reference instruments calibrated at Mauna Loa Observatory every 3 months. From the point of view of GNSS meteorology CIMEL is an independent source of IPW.

Several investigations have been carried out to evaluate sunphotometer IPW by other techniques, also GNSS (see e.g. Pérez-Ramírez et al., 2014). They acknowledge relatively low accuracy of IPW measured by sunphotometer (of about $10 \%)$. There is ongoing work with the procedure of IPW retrieval from sunphotometer measurements (Alexandrov et al., 2009). Most comprehensive intertechnique comparison (dealing mostly with satellite devices) got better GNSS-CIMEL agreement but also reports some CIMEL IPW bias dependent on IPW value (Van Malderen et al., 2014).

AERONET provides two versions of data IPW sets: level 1.5 (cloud-screened) and level 2.0 (cloud-screened and quality-assured). The IPW values are the same in both sets but precise calibrations and quality control for lev 2.0 set affects IPW comparison indirectly dropping out some measurements. So for lev 2.0 we have less data points.

Similar technique to sun photometry is a differential optical absorption spectrometry (DOAS) which measures intensity of individual spectral lines of atmospheric constituents. Their specific narrow band absorption structures are measured and converted to concentrations thanks to Lambert-Baer law (Platt, 1994). DOAS is more precise than simple photometry which measures total intensity of total spectral bands but much more costly. Sunphotometer measures overall channel intensity whereas DOAS retrieves spectral profile in detail. There are only a few experimental single constructions of DOAS water vapour spectrometers - e.g. Swiss - German SOLUSAR (Münch, 2014).

The only location in Central Europe where GPS, CIMEL and local meteorological data are simultaneously available is Central Geophysical Observatory Polish Academy of Sciences in Belsk. When our observations have been started in 2009 it constituted probably the first such co-location in the world. As preliminary results have been presented only in the form of posters (e.g Kruczyk et al., 2011; Kruczyk, 2012) some other publications emerged taking precedence over our research.

CIMEL sunphotometer at first is a genuine data source and can be utilized for external verification of new GPS tropospheric solution procedures, e.g. reprocessing. This was confirmed with the help of sunphotometer data for 2004-2006. IPW from tropospheric estimates after reprocessing (solution with use of new software, models and reference frame) is two times lower than before and close to $1 \mathrm{~mm}$ (Kruczyk \& Liwosz, 2012).

\section{Observation campaign at Belsk and GPS data processing}

Results from initial comparisons for JOZE EPN (EUREF Permanent Network) station and Belsk (for earlier years) turned out so interesting that we decided for direct colocation of GPS measurements and sunphotometer. There has been set up a periodic (semi-permanent) GPS station BELS on the roof of the building of Central Geophysical Observatory Institute of Geophysics PAS in Belsk (figure 2). Trimble 4000 SSE receiver (till May 2009 JOZE IGS/EPN station receiver) has been permanently installed on July 2009. It worked permanently till July 2012. 


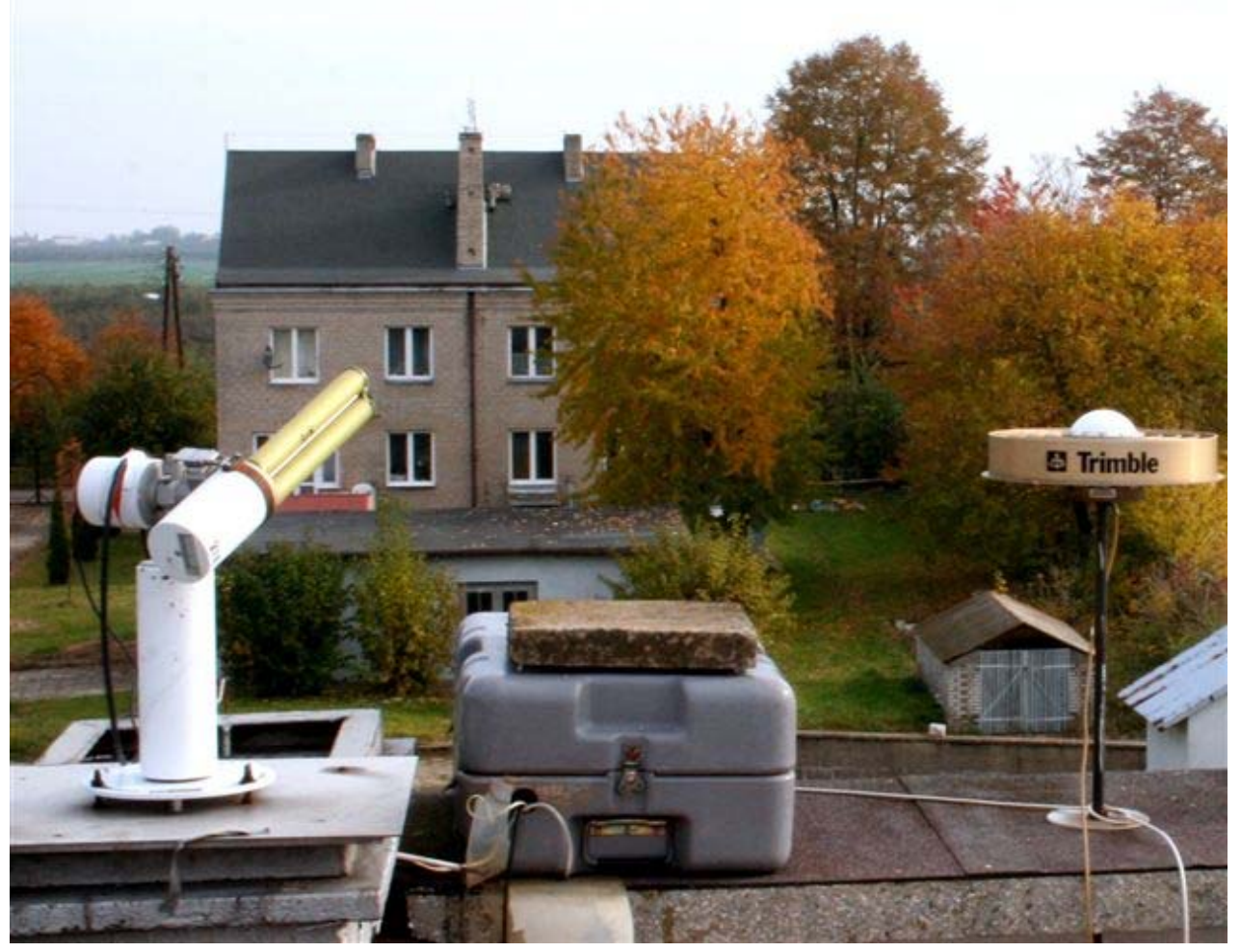

Fig. 2. CIMEL-318 and GPS antenna at Belsk

Two independent GPS processing procedures have been carried out: network solution and PPP (precise point positioning) solution by on-line service: CSRS-PPP (Canada Centre for Remote Sensing, Geodetic Survey Division, Natural Resources Canada).

\subsection{Network solution}

The campaign (data for September 2009 onwards) has been processed along WUT LAC (Warsaw University of Technology, Local Analysis Center of EPN) guidelines in the subset of stations (39 stations) also used in standard processing.

Main processing parameters by Bernese 5.0 software were as follows: elevation cut-off angle $-3^{\circ}$, sampling interval $-180 \mathrm{sec}$, sampling troposphere (estimation window) - 1 hour, trop mapping function - wet Niell (the rest can be seen on WUT LAC log file at EPN; Liwosz et al., 2010).

Quality of this solution for all stations was proved by comparison with EPN combined tropospheric product (standard product of EPN network created as iterative weighted mean of individual analysis centre solutions, for details see: Pacione et al., 2011). For all (except one) stations this solution in comparison with EPN combined tropospheric product show ZTD biases below $1 \mathrm{~mm}$ level. Generally satisfying results are as follows: average bias $0.3 \mathrm{~mm}$, difference RMS $1.87 \mathrm{~mm}$ (in 2010). 
Table 1. Comparison of ZTD from test campaign (WUT LAC dedicated solution for Belsk) with EPN combined tropospheric product. Note: BELF is Belfast, Belsk is not an EPN station.

\begin{tabular}{|c|c|c|c|c|c|}
\hline $\begin{array}{c}\text { GPS } \\
\text { station }\end{array}$ & $\begin{array}{c}\text { bias } \\
{[\mathrm{mm}]}\end{array}$ & $\begin{array}{c}\text { absolute } \\
\text { difference } \\
{[\mathrm{mm}]}\end{array}$ & $\begin{array}{c}\text { STDEV } \\
{[\mathrm{mm}]}\end{array}$ & $\begin{array}{c}\text { RMS } \\
{[\mathrm{mm}]}\end{array}$ & points \\
\hline BELF & -0.26 & 1.53 & 2 & 2.02 & 6292 \\
\hline BISK & 0.87 & 1.57 & 3.42 & 3.53 & 5905 \\
\hline BOGI & 0 & 1.31 & 1.77 & 1.77 & 5862 \\
\hline BOGO & 0.02 & 1.24 & 1.65 & 1.65 & 6250 \\
\hline BOR1 & 0.25 & 1.14 & 1.54 & 1.56 & 6381 \\
\hline BUTE & 0.01 & 1.58 & 2.13 & 2.13 & 6060 \\
\hline GANP & -0.19 & 1.33 & 1.77 & 1.78 & 6345 \\
\hline GLSV & 0.28 & 1.32 & 1.81 & 1.83 & 6284 \\
\hline GOPE & 0.5 & 1.31 & 1.68 & 1.75 & 6224 \\
\hline GWWL & 0.21 & 1.23 & 1.67 & 1.68 & 6260 \\
\hline HOE2 & 0.36 & 1.27 & 1.63 & 1.67 & 6216 \\
\hline INVR & -0.16 & 1.55 & 2.04 & 2.05 & 6368 \\
\hline JOZ2 & 0.19 & 1.17 & 1.6 & 1.61 & 6273 \\
\hline JOZE & -0.18 & 1.26 & 1.7 & 1.7 & 6330 \\
\hline KATO & 0.26 & 1.26 & 1.71 & 1.73 & 6059 \\
\hline KRAW & 0.23 & 1.17 & 1.59 & 1.61 & 6358 \\
\hline LAMA & 0.28 & 1.21 & 1.63 & 1.65 & 6293 \\
\hline METS & 0.1 & 1.2 & 1.66 & 1.66 & 4829 \\
\hline & & & & & \\
\hline
\end{tabular}

\begin{tabular}{|c|c|c|c|c|c|}
\hline $\begin{array}{c}\text { GPS } \\
\text { station }\end{array}$ & $\begin{array}{c}\text { bias } \\
{[\mathrm{mm}]}\end{array}$ & $\begin{array}{c}\text { absolute } \\
\text { difference } \\
{[\mathrm{mm}]}\end{array}$ & $\begin{array}{c}\text { STDEV } \\
{[\mathrm{mm}]}\end{array}$ & $\begin{array}{c}\text { RMS } \\
{[\mathrm{mm}]}\end{array}$ & points \\
\hline ONSA & 0.01 & 1.14 & 1.53 & 1.53 & 6308 \\
\hline PENC & 0.22 & 1.36 & 1.78 & 1.79 & 6270 \\
\hline POTS & 0.18 & 1.23 & 1.67 & 1.68 & 6329 \\
\hline REDZ & 0.22 & 1.14 & 1.57 & 1.59 & 6223 \\
\hline RIGA & -0.09 & 1.31 & 1.79 & 1.79 & 6357 \\
\hline SASS & 0.51 & 1.2 & 1.51 & 1.59 & 6328 \\
\hline SULP & 0.28 & 1.42 & 1.92 & 1.94 & 3304 \\
\hline SWKI & 0.69 & 1.19 & 1.41 & 1.57 & 6243 \\
\hline TRF2 & 0.28 & 1.61 & 2.25 & 2.27 & 5939 \\
\hline TUBO & 0.58 & 1.47 & 1.85 & 1.94 & 6102 \\
\hline USDL & 0.59 & 1.36 & 1.72 & 1.82 & 6275 \\
\hline UZHL & 0.95 & 1.83 & 2.54 & 2.71 & 4576 \\
\hline VIS0 & 0.52 & 1.32 & 1.74 & 1.81 & 6277 \\
\hline WROC & 0.4 & 1.14 & 1.48 & 1.53 & 6346 \\
\hline WTZR & 0.5 & 1.59 & 2.06 & 2.12 & 6287 \\
\hline ZIM2 & 1.51 & 1.98 & 2.05 & 2.55 & 6276 \\
\hline ZYWI & 0.46 & 1.26 & 1.61 & 1.68 & 6127 \\
\hline & & & & &
\end{tabular}

On the way to above results impact of the use of new reference frame IGS08 vs. older IGS05 have been tested in the initial years of Belsk campaign (2009-2010). Reference frame change results in slight difference in ZTD estimates: average difference ZTD IGS08 (used in this work) - ZTD IGS05 = -0.5 mm in 2010; average RMS $=1.7 \mathrm{~mm}$. It could affect only slightly IPW values. No dependence of ZTD to GPS orbits used in tropospheric solution (final vs. ultra rapid) has been detected: in this case bias is not present and average difference RMS is only $0.5 \mathrm{~mm}$.

\subsection{Precise point positioning solution for Belsk}

The period of 2010-2012 of GPS observations at Belsk has been worked out by automatic CSRS-PPP (V 1.05) PPP-On-Line Positioning Service. It is freely available (after log-in) by the webpage of NRCan (National Resources of Canada): http://www.geod.nrcan.gc.ca. The service is a tool dedicated to positioning but provides also tropospheric estimates in 30-sec interval. Essential solution parameters are:

- orbits/clocks: IGS final

- reference frame: IGS08

- cut-off angle $10^{\circ}$

- L3 combination

- a-priori tropospheric model: Davies (hydrostatic part), Hopfield (wet)

- mapping function: GMF

- troposphere and coordinates estimated for every epoch (here $30 \mathrm{sec}$ )

Solution procedure includes extensive filtering (narrow lane- and wide linecombination, multipath level etc.) but final Kalman filtering leaves some unacceptable deviations at the beginning of each file. Fortunately only a dozen or so first records are affected. Results are related to formal solution error so it is easy to reject then: we used $13 \mathrm{~mm}$ ZTD level as a criterion. 
Meteorological measurements at Belsk are available in 5 min interval so ZTD PPP estimates have been averaged over 300 seconds steps (mid-range for epochs 0300600 900). To compare our results with the network solution hourly averages have also been made. The results are presented in table 2: WUT(B) means dedicated network solution for Belsk described in the previous chapter).

Table 2. Network ZTD solution vs. PPP ZTD solution for Belsk -statistics of comparison (bias: WUT(B) - PPP)

\begin{tabular}{|c|c|c|c|c|c|c|}
\hline & $\begin{array}{c}\text { network solution } \\
\text { reference frame }\end{array}$ & $\begin{array}{c}\text { bias } \\
{[\mathrm{mm}]}\end{array}$ & $\begin{array}{c}\text { absolute } \\
\text { difference [mm] }\end{array}$ & $\begin{array}{c}\text { difference } \\
\text { std dev }\end{array}$ & $\begin{array}{c}\text { difference } \\
\text { RMS [mm] }\end{array}$ & $\begin{array}{c}\text { number } \\
\text { differences }\end{array}$ \\
\hline 2010 & igs08 & -0.68 & 3.86 & 5.25 & 5.30 & 6218 \\
\hline 2010 & igs05 & -0.98 & 3.86 & 5.20 & 5.29 & 5961 \\
\hline 2011 & igs08 & -1.79 & 4.29 & 5.81 & 6.08 & 5718 \\
\hline 2012 & igs08 & -1.20 & 3.86 & 5.31 & 5.45 & 4401 \\
\hline
\end{tabular}

IPW has been calculated due to the procedure described in the chapter 2 and presented in the Fig. 3. This IPW series is subject to further comparisons with CIMEL precipitable water retrievals.

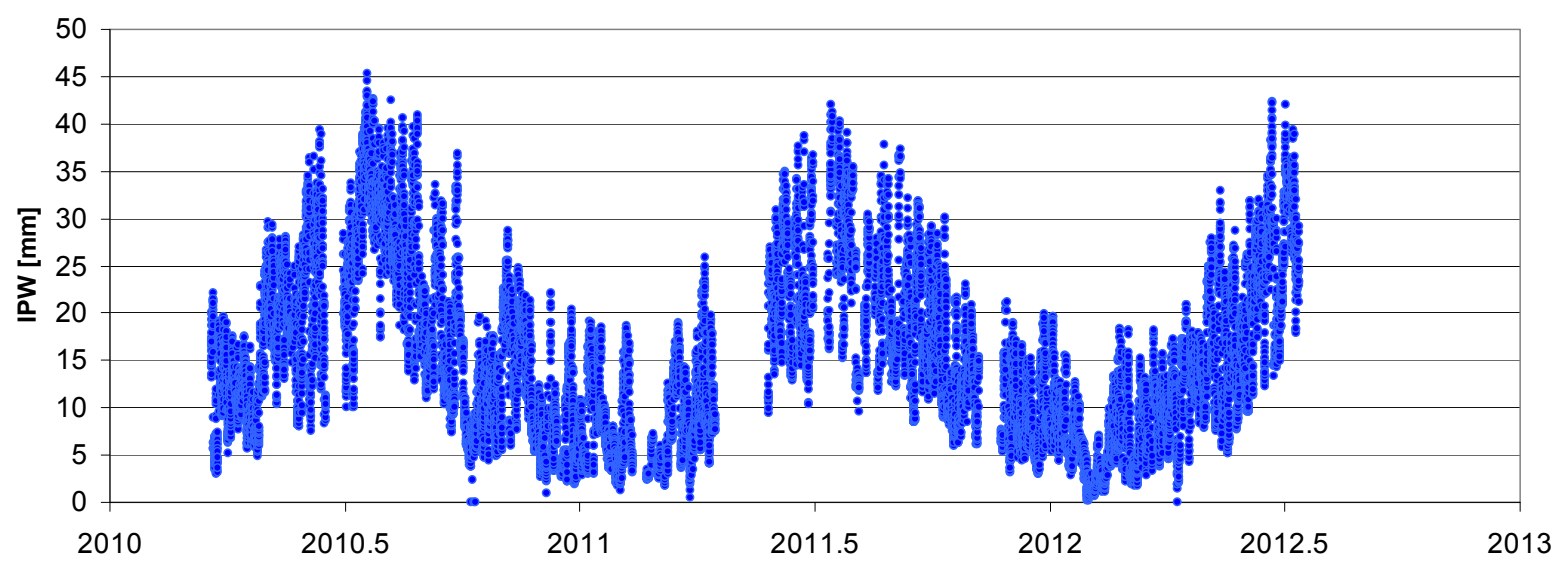

Fig. 3. Belsk IPW (GPS PPP solution, hourly interval) - 2010-2012

\section{Analysis of the results - IPW comparison (CIMEL and GPS)}

After transforming ZTD to IPW, by procedure described briefly in the chapter 2, conformity with CIMEL-318 IPW values was analysed. For this purpose CIMEL IPW values were averaged in 1 hour spans because of network GPS solution also gives hourly values of tropospheric delay estimates.

Crucial point of this experiment: co-location of GPS station with CIMEL-318 sunphotometer is realized by IPW comparison. The results of comparison of IPW from GPS and CIMEL are illustrated on the figures: 4, 5 and 6 and detailed in tables: 3 and 4 . Also 5 min averaged intervals have been compared with individual CIMEL measurements for PPP solution (not only hourly averages like in network solution case). Network solution (processing of BELS station in the subset of EPN network) result in IPW biases of only the fraction of millimetre (shown on figure 4). IPW comparison was tried also for more distant GNSS stations. There are two permanent GNSS EPN/IGS stations near Warsaw: Józefosław (JOZE, JOZ2 points) and Borowa Góra (BOGO, BOGI points). IPW differences for JOZE and BOGI (in relation to Belsk sunphotometer) give characteristic pattern of growing dispersion (figures 6 and 7). 


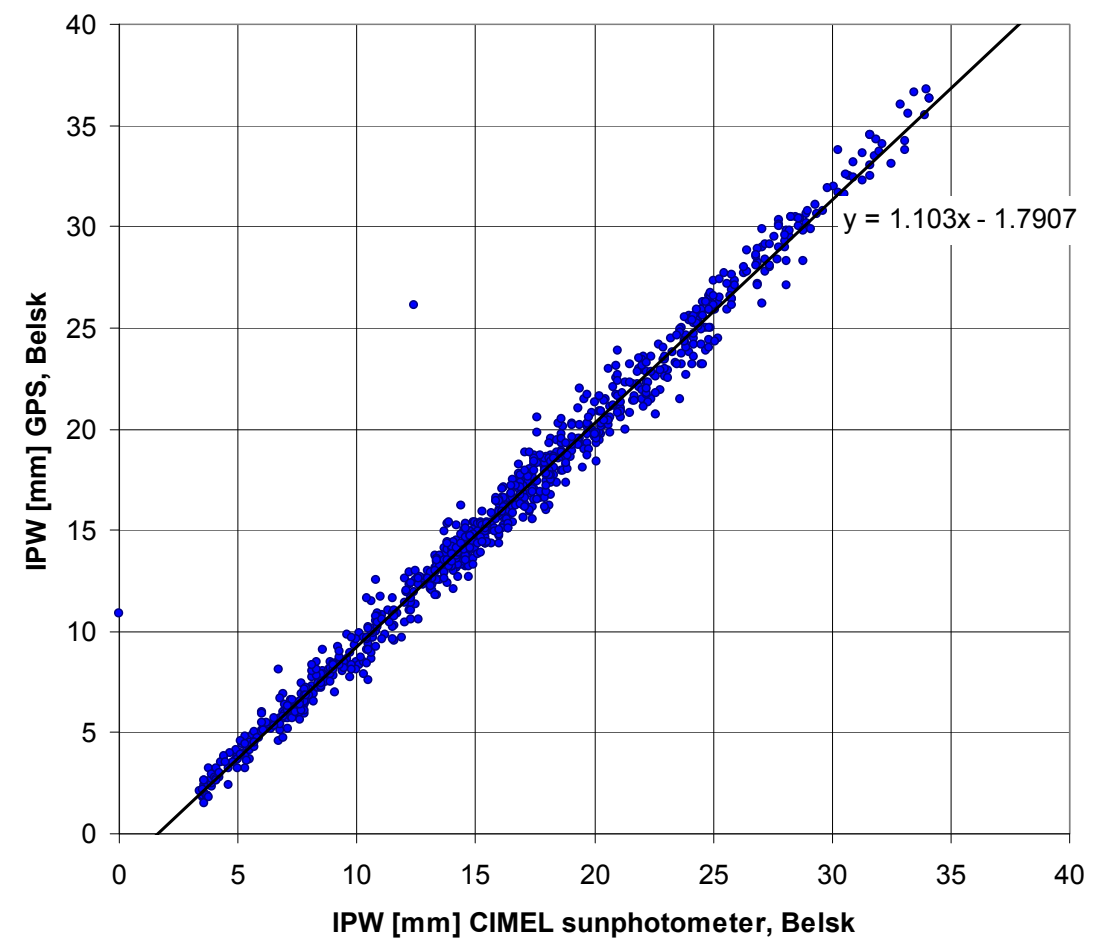

Fig. 4. Belsk IPW: CIMEL-318 measurements and GPS BELS (WUT dedicated hourly solution), correlation 0.993 , bias $0.23 \mathrm{~mm}$
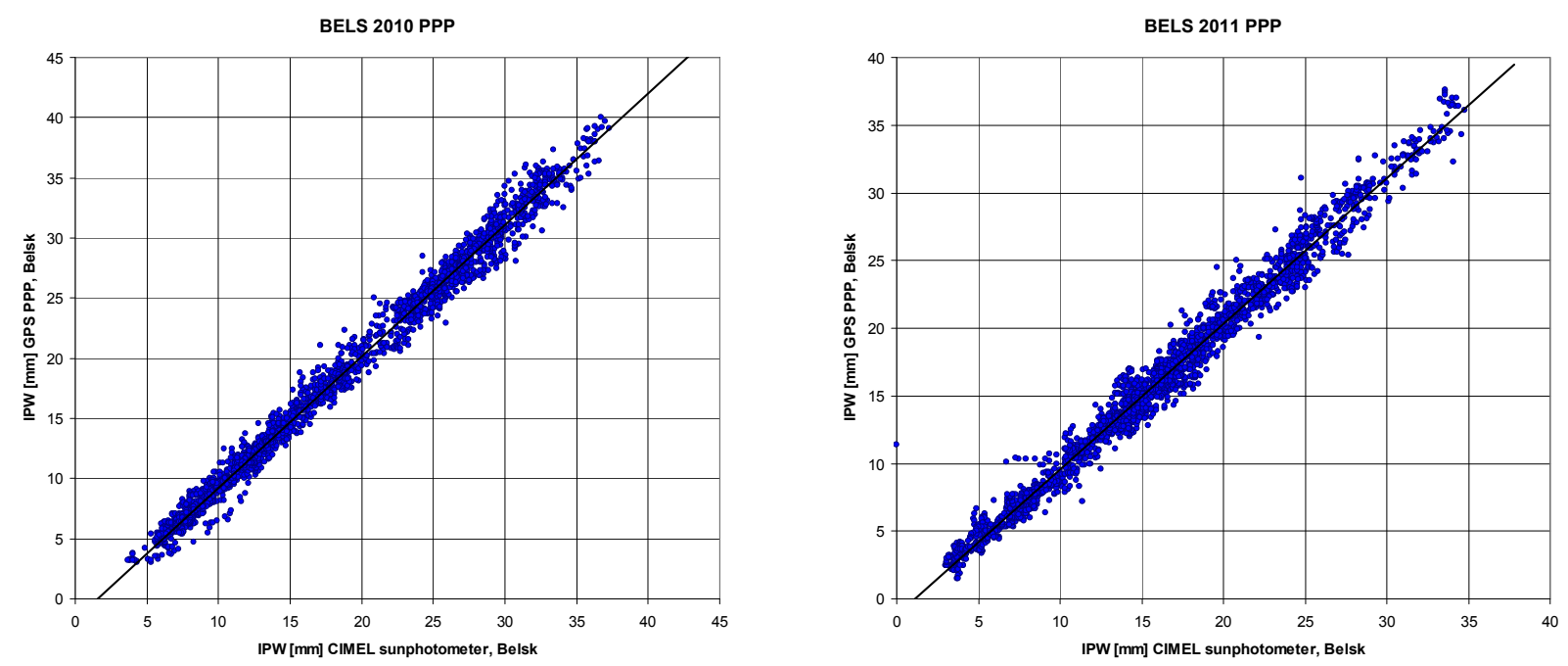

Fig. 5. Belsk IPW CIMEL (lev 2.0) vs. GPS PPP solution (5 minute interval) in 2010 and 2011 

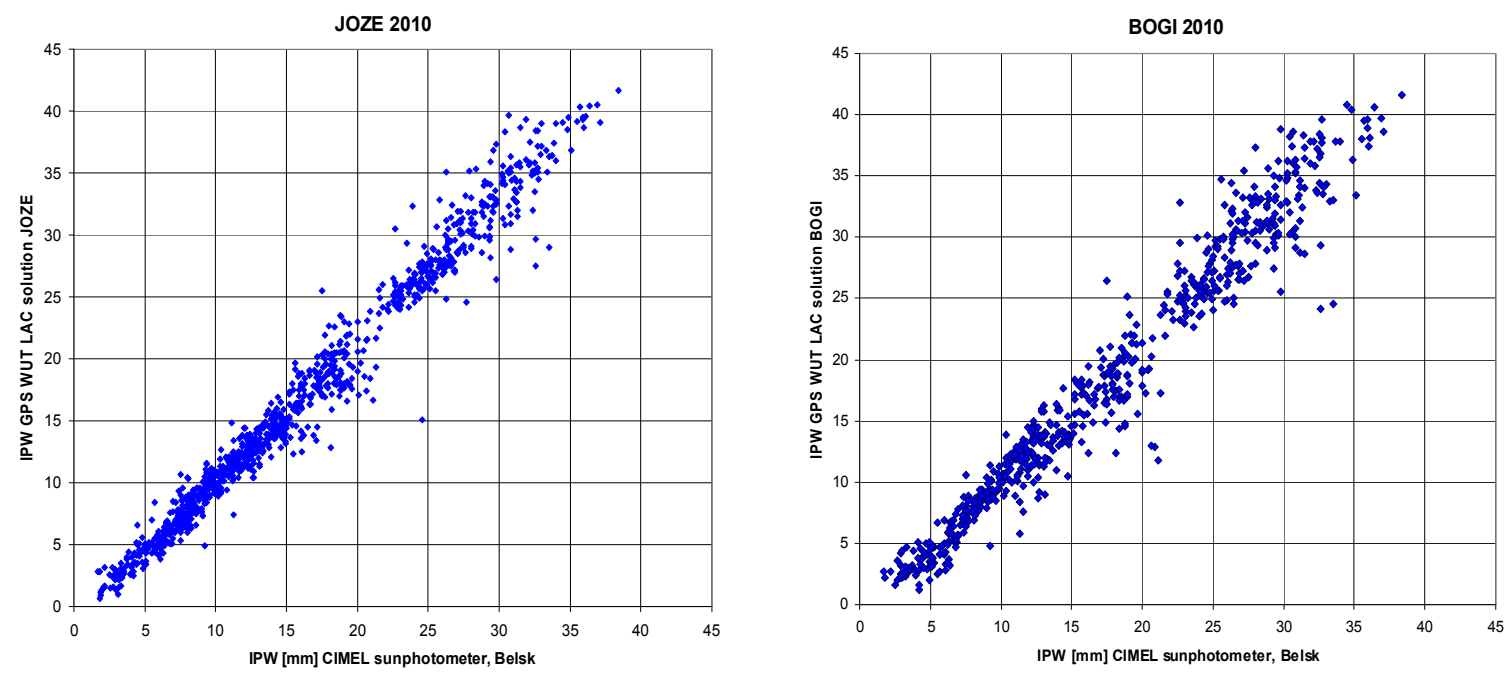

Fig. 6. Belsk IPW - CIMEL-318 measurements and GPS IPW BELS, JOZE and BOGI (WUT dedicated solution) in 2010

In the year 2010, presented in the figure 6, Belsk CIMEL and JOZE GPS correlation coefficient is: 0.988, Belsk CIMEL and BOGI GPS: 0.979. Belsk - JOZE distance is $33 \mathrm{~km}$ and Belsk BOGl - $73 \mathrm{~km}$. The same effect is much more clearly visible in shorter time series (IPW changes thorough the whole year are amplified by seasonal cycle). When we set aside photometer and GPS IPW for just 3 months (September-November), available in 2009, dispersion bound up with increasing distance of techniques is obvious (figure 7).

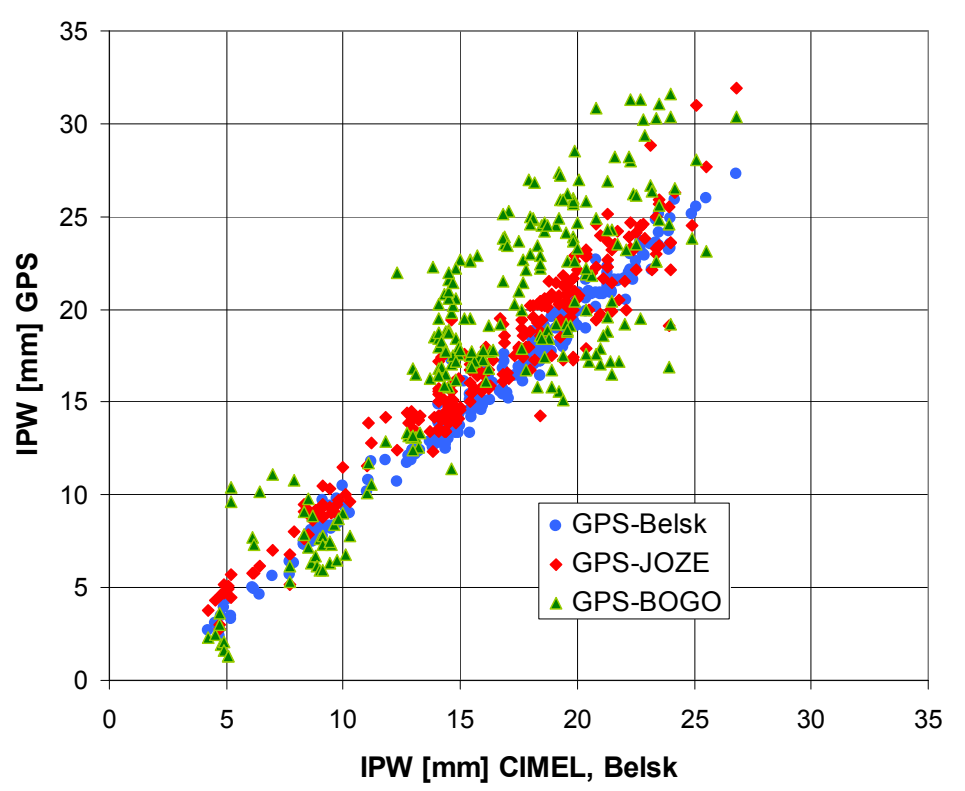

Fig. 7. Belsk IPW (CIMEL-318 measurements lev 2.0) and GPS BELS, JOZE and BOGI (WUT dedicated solution) in 2009

Summary of results of CIMEL vs. GPS comparisons utilising point BELS and 4 close EPN GNSS permanent stations (and different solutions) is presented in the table 3. Also two separate sets of CIMEL IPW: lev 1.5 and lev 2.0 cloud-screened and quality-assured data (smaller set of data but with the same values; see chapter 3) have been used. To compare IPW we need the GPS ZTD estimates (GPS 
observations functioning), local meteorological data and CIMEL measurements at the same time - otherwise gaps will occur. Hence there are several gaps in our IPW comparisons.

Table 3 Statistics of comparison of IPW from CIMEL -318 and close GPS stations (three independent GPS solutions: dedicated WUT LAC solution, WUT LAC solution for EPN, EPN tropospheric product) in 2011

\begin{tabular}{|c|c|c|c|c|c|c|c|c|}
\hline CIMEL & GPS & solution & $\begin{array}{c}\text { bias [mm] } \\
\text { (CIMEL } \\
\text { - GPS) }\end{array}$ & $\begin{array}{c}\text { mean } \\
\text { absolute } \\
\text { bias [mm] }\end{array}$ & $\begin{array}{l}\text { difference } \\
\text { std dev }\end{array}$ & $\begin{array}{l}\text { difference } \\
\text { RMS [mm] }\end{array}$ & $\begin{array}{c}\text { no of } \\
\text { estimates } \\
\text { (ZTD) }\end{array}$ & $\begin{array}{c}\text { no of CIMEL } \\
\text { measurements }\end{array}$ \\
\hline \multirow{11}{*}{ Belsk lev20 } & BELS & dedicated & 0.13 & 0.92 & 1.12 & 1.12 & 868 & 2901 \\
\hline & JOZ2 & EUR comb & -0.32 & 1.30 & 1.72 & 1.75 & 1188 & 3966 \\
\hline & JOZ2 & dedicated & -0.52 & 1.34 & 1.78 & 1.85 & 881 & 2949 \\
\hline & JOZ2 & WUT LAC & -0.29 & 1.32 & 1.76 & 1.79 & 1175 & 3918 \\
\hline & JOZE & EUR comb & -0.77 & 1.45 & 1.84 & 2.00 & 1192 & 3971 \\
\hline & JOZE & dedicated & -0.97 & 1.55 & 1.91 & 2.14 & 892 & 2971 \\
\hline & JOZE & WUT LAC & -0.71 & 1.44 & 1.86 & 1.99 & 1190 & 3958 \\
\hline & BOGI & EUR comb & -1.00 & 1.91 & 2.44 & 2.64 & 806 & 2568 \\
\hline & BOGI & dedicated & -1.17 & 1.96 & 2.42 & 2.69 & 586 & 1889 \\
\hline & BOGI & WUT LAC & -0.91 & 1.88 & 2.44 & 2.60 & 806 & 2568 \\
\hline & BOGO & dedicated & -0.85 & 1.93 & 2.49 & 2.63 & 582 & 1879 \\
\hline \multirow{9}{*}{ Belsk lev15 } & BELS & dedicated & 0.12 & 0.92 & 1.13 & 1.13 & $\overline{936}$ & 3024 \\
\hline & JOZ2 & EUR comb & -0.30 & 1.29 & 1.72 & 1.75 & 1270 & 4106 \\
\hline & JOZ2 & dedicated & -0.52 & 1.34 & 1.78 & 1.86 & 945 & 3064 \\
\hline & JOZ2 & WUT LAC & -0.28 & 1.31 & 1.76 & 1.79 & 1257 & 4058 \\
\hline & JOZE & EUR comb & -0.76 & 1.44 & 1.84 & 1.99 & 1281 & 4123 \\
\hline & JOZE & dedicated & -0.97 & 1.54 & 1.90 & 2.13 & 963 & 3098 \\
\hline & JOZE & WUT LAC & -0.70 & 1.44 & 1.85 & 1.98 & 1279 & 4110 \\
\hline & BOGI & EUR comb & -0.96 & 1.88 & 2.43 & 2.61 & 854 & 2638 \\
\hline & BOGI & dedicated & -1.16 & 1.93 & 2.39 & 2.66 & 619 & 1935 \\
\hline
\end{tabular}

Table 4 IPW from CIMEL vs. IPW from PPP ZTD solution for Belsk -statistics of comparison (bias: CIMEL - GPS PPP); absolute difference means: averaged module of differences

\begin{tabular}{|c|c|c|c|c|c|c|c|}
\hline year & $\begin{array}{c}\text { ZTD } \\
\text { interval }\end{array}$ & CIMEL & $\begin{array}{c}\text { IPW bias } \\
{[\mathrm{mm}]}\end{array}$ & $\begin{array}{c}\text { absolute } \\
\text { difference [mm] }\end{array}$ & $\begin{array}{c}\text { difference } \\
\text { std dev }\end{array}$ & $\begin{array}{c}\text { difference } \\
\text { RMS [mm] }\end{array}$ & points \\
\hline 2010 & $5 \mathrm{~min}$ & lev15 & 0.08 & 0.94 & 1.17 & 1.17 & 3159 \\
\hline 2010 & $5 \mathrm{~min}$ & lev20 & 0.08 & 0.94 & 1.17 & 1.17 & 3044 \\
\hline 2010 & $1 \mathrm{~h}$ & lev15 & -0.03 & 0.92 & 1.17 & 1.17 & 1012 \\
\hline 2010 & $1 \mathrm{~h}$ & lev20 & -0.02 & 0.92 & 1.16 & 1.16 & 947 \\
\hline 2011 & $5 \mathrm{~min}$ & lev15 & 0.03 & 0.88 & 1.14 & 1.14 & 2792 \\
\hline 2011 & $1 \mathrm{~h}$ & lev15 & -0.10 & 0.96 & 1.38 & 1.38 & 920 \\
\hline 2012 & $5 \mathrm{~min}$ & lev15 & 0.37 & 0.94 & 1.10 & 1.16 & 2641 \\
\hline 2012 & $1 \mathrm{~h}$ & lev15 & 0.28 & 0.90 & 1.08 & 1.12 & 821 \\
\hline
\end{tabular}

There are visible seasonal changes of IPW bias presented in the figures 8 (network solution) and 9 (PPP solution). Now let us dwell on analysis of difference series. Time dependent (seasonal) difference changes, very similar to these obtained for network solution, are also present - this time with much greater amount of measurements. Agreement of both techniques is excellent for annual averages (except for uncompleted year 2012 - observations stopped in July due to technical reasons; see table 5). Intriguing seasonal changes of IPW differences (CIMEL GPS) are presented together in figure 10. The IPW difference series for the whole campaign (September 2009 - July 2012) has been fitted with a simple model (annual and semi-annual term plus linear trend) by means of classical least squares method (figure 11). The estimated semi-annual amplitude is much smaller than annual but still detectable. 


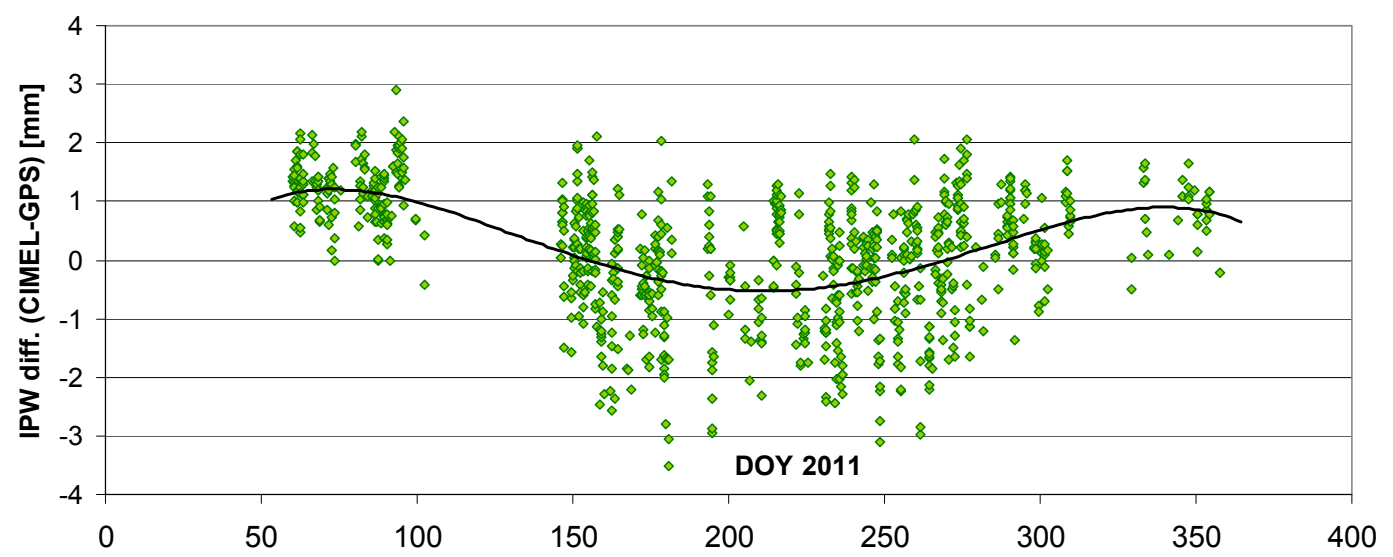

Fig. 8. IPW difference [mm] CIMEL-318 measurements minus GPS BELS (WUT dedicated solution) in 2011

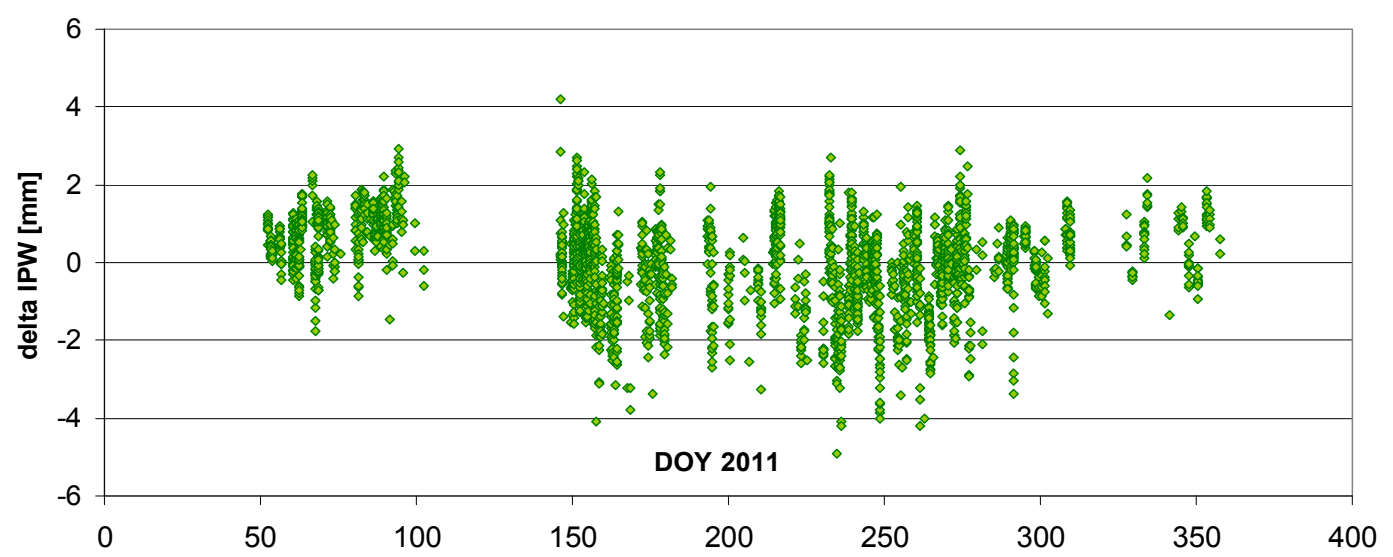

Fig. 9. Belsk IPW difference CIMEL - GPS PPP solution (5 minute interval) in 2011

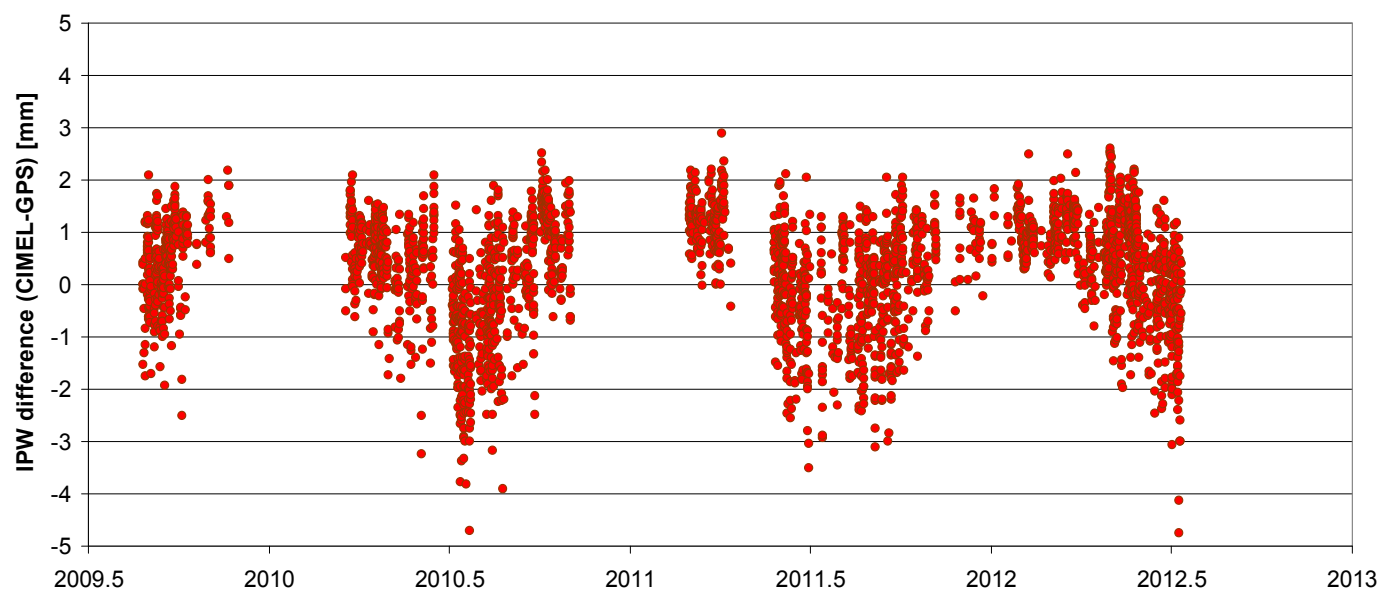

Fig. 10. IPW difference [mm] CIMEL-318 - GPS BELS (WUT dedicated solution) for the whole campaign September 2009- July 2012 (3009 points)

The difference series can be modelled by linear trend and two sinusoids (annual and semi-annual) both for the network solution and the PPP solution (figures 11 and 12). Only for PPP solution (5 min intervals) there are more estimates/measurements: each single CIMEL measurement was used for comparison - not the hourly averages. Table 5 summarises the resulted difference models for both network and PPP solution. 


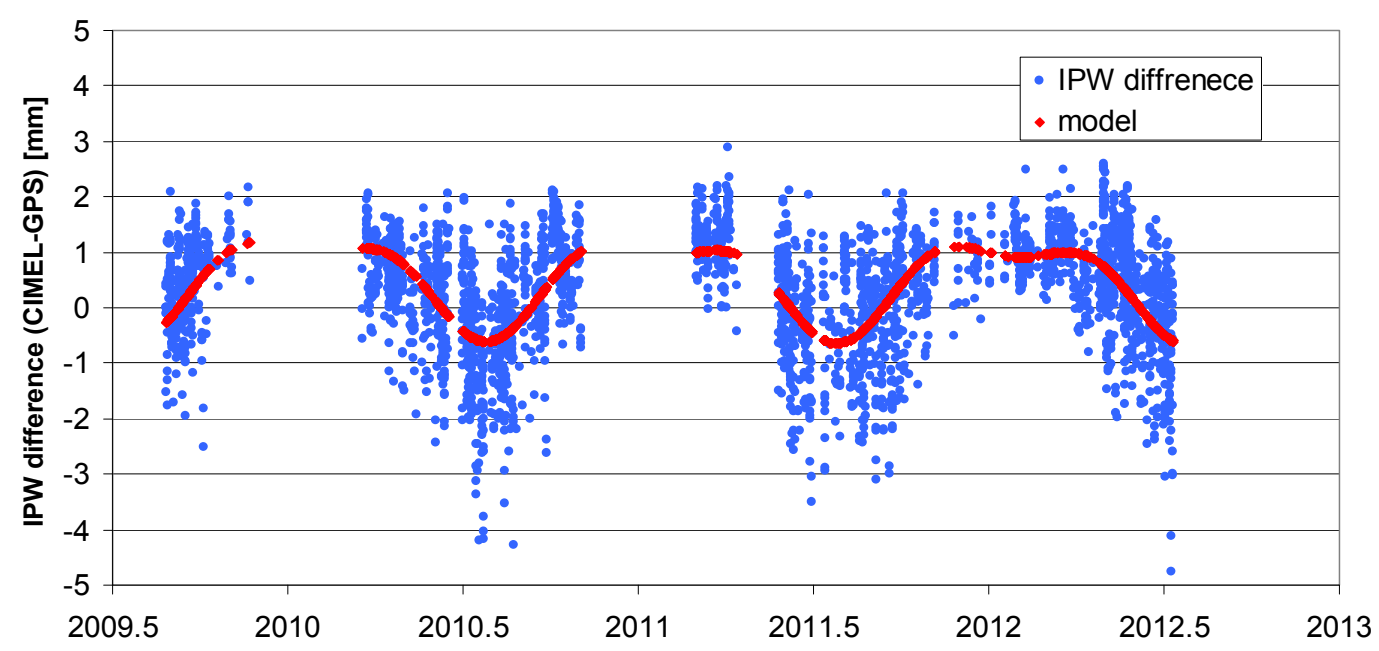

Fig. 11. IPW difference [mm] (CIMEL - GPS) and simple model (annual and semi-annual term plus linear trend) for the whole campaign September 2009- July 2012

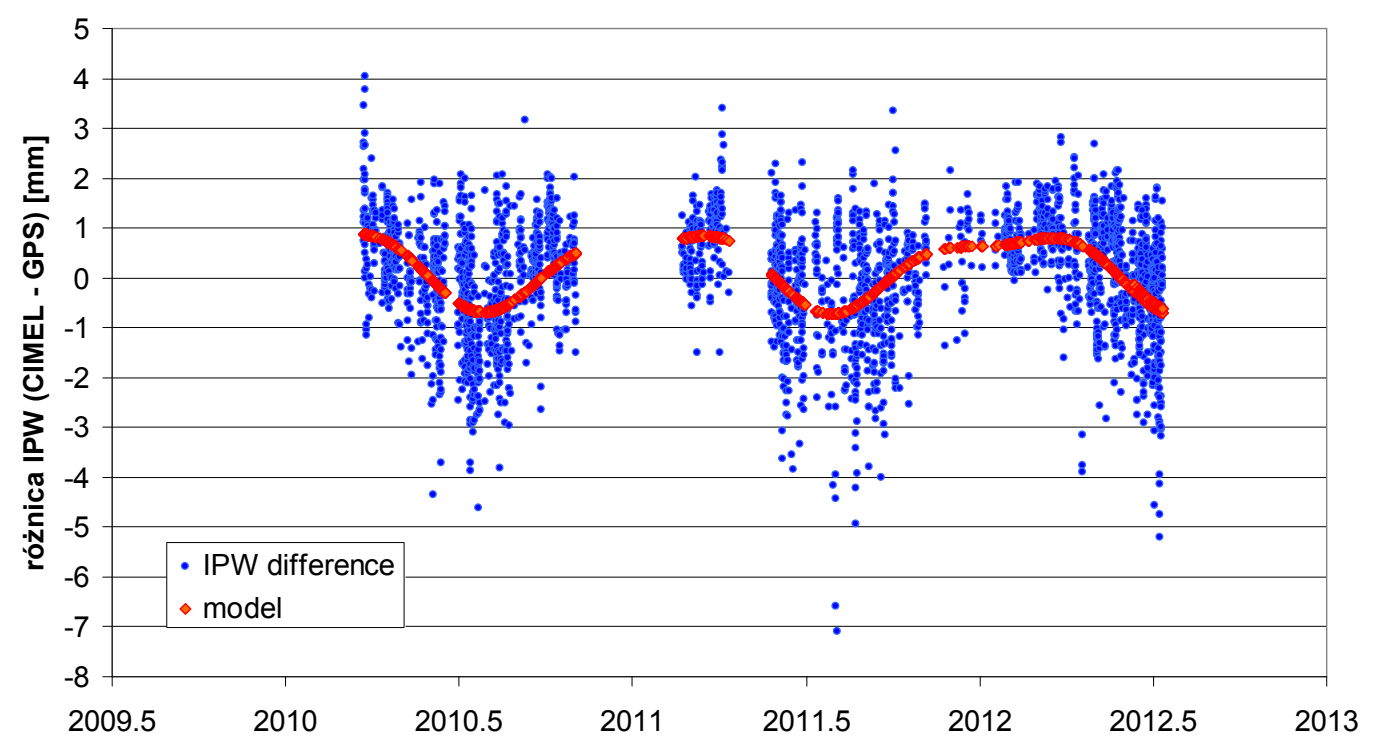

Fig. 12. Belsk IPW difference (CIMEL - GPS PPP solution) model for (March 2010-July 2012) for hourly averages (2952 points)

Table 5. Parameters of simple model of IPW differences (CIMEL- GPS) adjusted with least squares method for dedicated WUT LAC solution, PPP solution in 5 min intervals and hourly averages of PPP solution

\begin{tabular}{|l|c|c|c|}
\hline IPW bias model parameter & $\begin{array}{c}\text { network } \\
\text { solution }\end{array}$ & $\begin{array}{c}\text { PPP 5 minute } \\
\text { intervals }\end{array}$ & $\begin{array}{c}\text { PPP hourly } \\
\text { averages }\end{array}$ \\
\hline constant [mm] & 0.58 & 0.37 & 0.29 \\
\hline linear trend [mm/year] & -0.034 & -0.04 & -0.04 \\
\hline annual amplitude [mm] & 0.79 & 0.68 & 0.71 \\
\hline annual phase $\left[^{\circ}\right.$ ] & $21^{\circ}$ & $29^{\circ}$ & $31^{\circ}$ \\
\hline semi-annual amplitude [mm] & 0.36 & 0.30 & 0.26 \\
\hline semi-annual phase [ ${ }^{\circ}$ ] & $-130^{\circ}$ & $-138^{\circ}$ & $-137^{\circ}$ \\
\hline residuals RMS [mm] & 0.93 & 1.02 & 1.11 \\
\hline no of comparison points & 2952 & 8592 & 2953 \\
\hline
\end{tabular}


Results of the fitting are strikingly similar (especially phases) to the same model parameters for network solution. In case of PPP smaller semi-annual amplitude and slightly greater RMS have been obtained.

Residuals of IPW differences (after applying model listed above) do not show any obvious regularity, except of course greater dispersion in the summer when IPW values are considerably bigger (figure 13). There is some slight trend discernible when we plot residuals against IPW values (figure 14) - that reminds us that annual/semi-annual model not ideal.

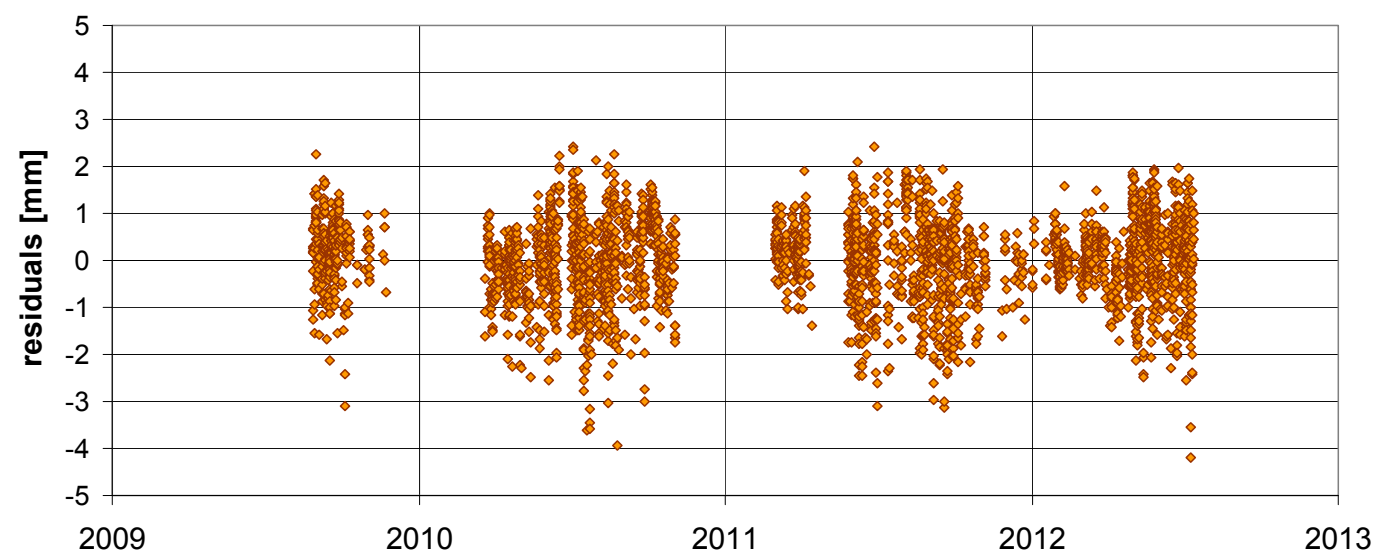

Fig. 13. Residuals [mm] after applying of simple model (annual and semi-annual term plus linear trend) to the IPW differences (CIMEL - GPS network solution)

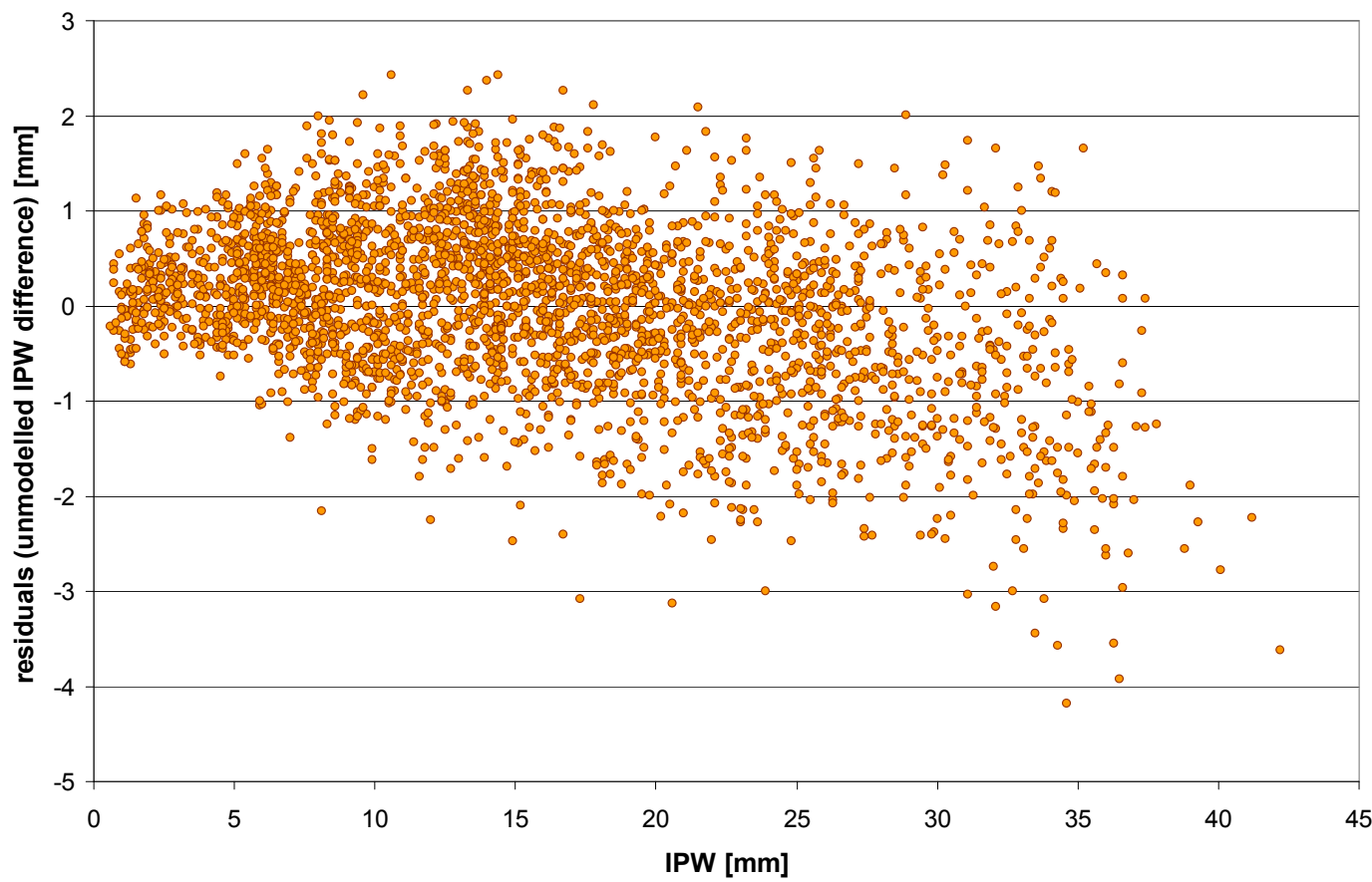

Fig. 14. Residuals [mm] (un-modelled CIMEL - GPS IPW difference plotted against IPW values (network solution; the same data as in the figure 13)

The most obvious cause to any seasonal cycles in the environment in the moderate latitudes is atmospheric temperature (depending on insolation). IPW differences really show distinct dependence on atmospheric surface temperatures registered at Belsk for both GPS solutions (figures 15 and 16). 


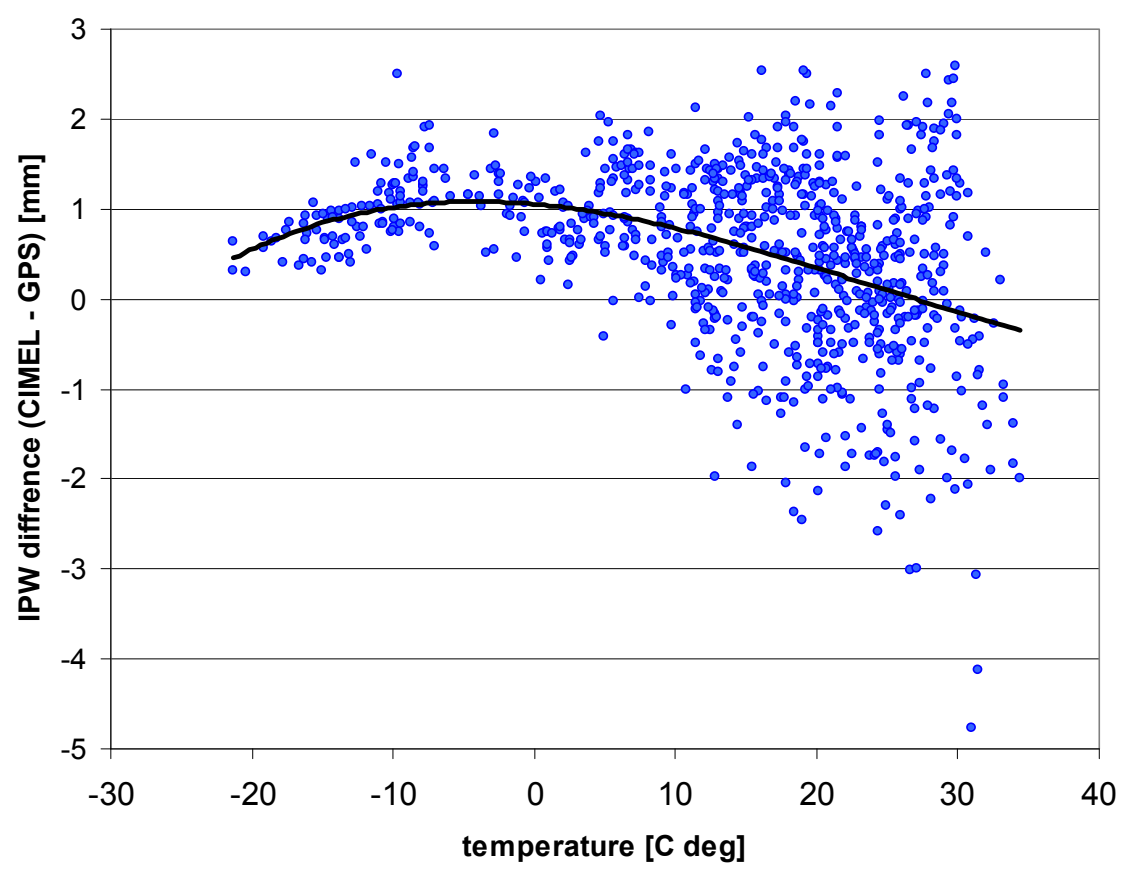

Fig. 15. IPW difference [mm] CIMEL-318 - GPS BELS (network solution) as a function of atmospheric surface temperature in 2012

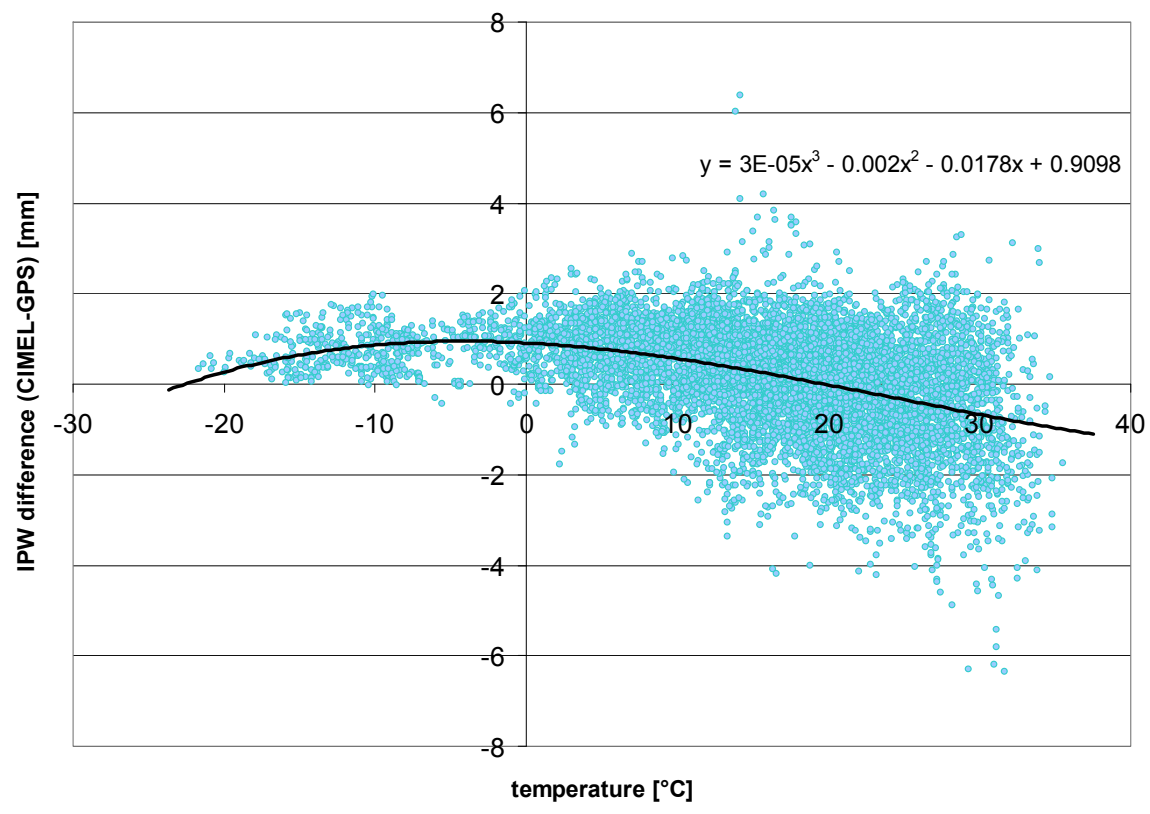

Fig. 16. IPW difference [mm] CIMEL-318 - GPS PPP solution for Belsk as a function of atmospheric temperature in 2010-2012 (5 minute interval) with trend line (8592 points)

IPW difference temperature dependence is even more obvious for single CIMEL measurements than hourly averages: for comparison with 5 min PPP tropospheric solution.

The increase of differences dispersion at the right side on above figure is easily comprehensible if we take into account features of water vapour itself. Saturated water vapour content in the atmosphere at any point rises exponentially with temperature (as acknowledged in any textbook of meteorology e.g. Mcllven, 2010, 
chapter 6.2). The real water vapour content is only a variable fraction of saturated density but still conforms to this general pattern. You can check this in the figure 17, which describes IPW in relation to atmospheric surface temperature $(2 \mathrm{~m})$ for period of 2010-2012 at Belsk. Figure 17 also shows the impact on IPW by the weather variability but these effects do not explain the inter-technique (GPS-CIMEL) IPW bias.

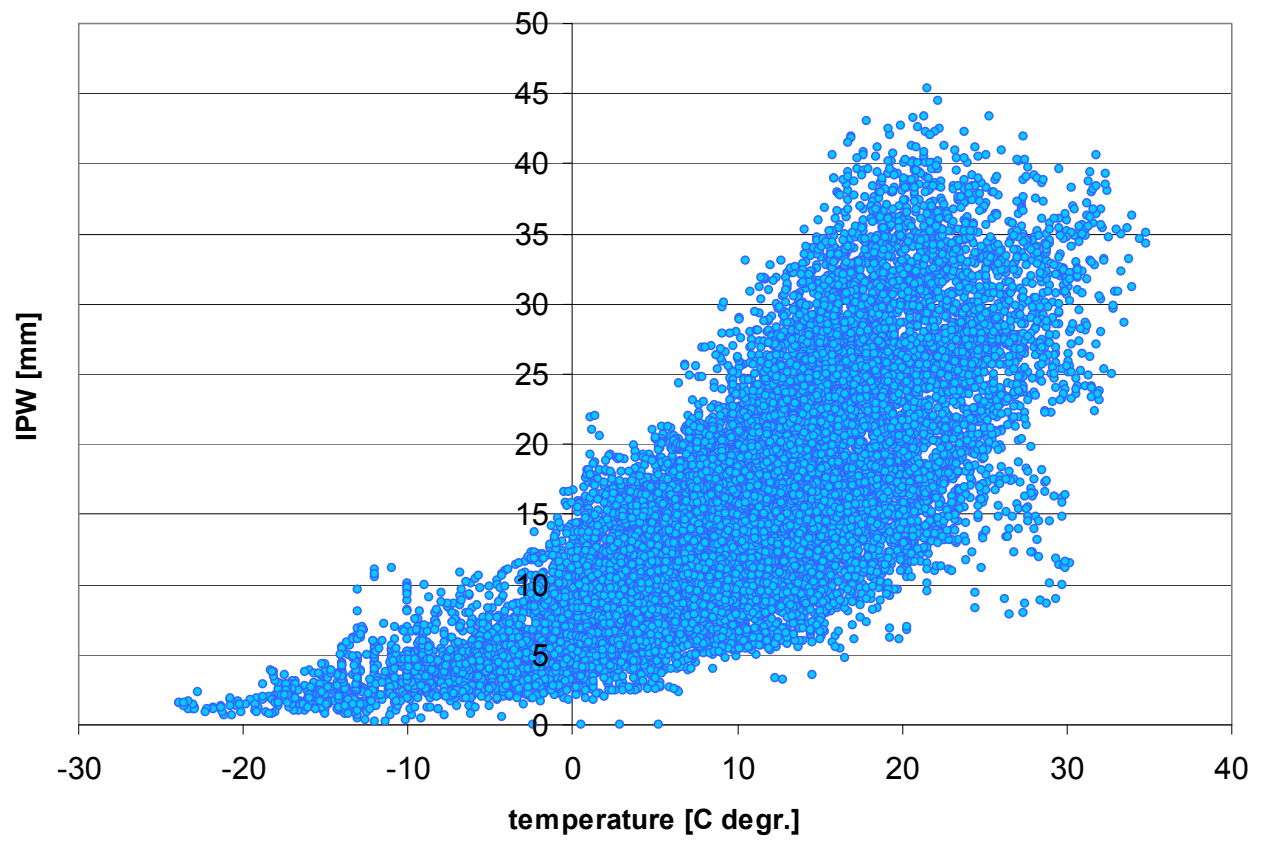

Fig. 17. IPW [mm] from GPS network solution for Belsk as a function of atmospheric surface temperature in 2010-2012

\section{Conclusions}

Independent techniques to obtain Integrated Precipitable Water have been tested in one point in Central Europe: GPS solution and CIMEL sunphotometer at Central Geophysical Observatory PAS, south of Warsaw. Two different GPS methodes of tropospheric parameter estimation have been investigated: network solution and PPP solution by CSRS-PPP (NRCan). CIMEL sunphotometer IPW and IPW values derived by in situ GPS observation campaign for Belsk are very similar: bias less than $1 \%$. IPW differences show distinct seasonal dependence which is more complicated than simple periodic terms. There is a clear correlation of IPW bias and local atmospheric temperature. This phenomenon probably reflects temperature dependence of transmittance parameters of the optical filter in CIMEL-318 (the instrument is not thermostatised).

Paper demonstrates some deficiency of important IPW retrieval technique: CIMEL318 sun photometer thanks to verification by GPS. Investigation concern one station with data over a 3 years period and includes two completely different GPS solutions.

\section{Acknowledgement}

- This research was financially supported by the grant No. N N526 074038 of the Polish Ministry of Science and Higher Education/ National Centre of Science

- Brent Holben and Alexander Smirnov, NASA GSFC, AERONET - sunphotometer data analysis lev 1.5/2.0, helpful hints and literature sent

- Janusz Krzyścin, Jakub Wink, Grzegorz Karasiński, Institute of Geophysics, Polish 
Academy of Sciences

- Jerzy Rogowski, Naval Academy Gdynia (formerly at Warsaw University of Technology)

- EPN tropospheric product developers (Wolfgang Söhne and Rosa Pacione)

\section{References}

Alexandrov, M.A., Schmid, B., Turner, D.D., Cairns, B., Oinas, V., Lacis, A.A., Gutman, S.I., Westwater, E.R., A. Smirnov \& J. Eilers (2009). Columnar water vapor retrievals from MFRSR data, J.Geophys.Res., 114, D02306, DOI:10.1029/2008JD010543

Bevis, M., Businger, S., Herring, T., Rocken, C., Anthes, R., \& R. Ware (1992). GPS Meteorology: Remote Sensing of Atmospheric Water Vapour using the Global Positioning System, J. Geophys. Res., 97, pp. 15 787-15 801

Bevis, M., Businger, S., Chiswell, S., Herring, T. A., Anthes, R.A., Rocken, C., \& R. Ware (1994). GPS Meteorology: Mapping Zenith Wet Delays onto Precipitable Water, Journal of Applied Meteorology, Vol. 33, pp. 379-386

Böhm, J. \& Schuh, H., (2013). Atmospheric Effects in Space Geodesy, Springer Heidelberg New York Dordrecht London, DOI:10.1007/978-3-642-36932-2

Davis, J. L., Herring, T. A., Shapiro, I. I., Rogers, A. E. \& G. Elgered (1985). Geodesy by radio interferometry: Effects of atmospheric modeling errors on estimates of baseline length, Radio Science, 20, pp. 1593-1607

Duan, J., Bevis, M., Fang, P., Bock, Y., Chiswell, S., Businger, S., Rocken, C., Solheim, F., Van Hove, T., Ware, R., McClusky, S., Herring, T. A. \& King, R. W. (1996). GPS meteorology: direct estimation of the absolute value of precipitable water. J. Applied Met. 35, pp. 830-838

Halthore, R.N., Eck, T.F., Holben, B.N. \& B.L. Markham (1997). Sunphotometric Measurements of Atmospheric Water Vapor Column Abundance in the 940-nm Band. J. Geophys. Res., 102, pp 4343-4352

Holben, B.N., T.F.Eck, I.Slutsker, D.Tanre, J.P.Buis, A.Setzer, E.Vermote, J.A.Reagan, Y.J.Kaufman, T.Nakajima, F.Lavenu, I.Jankowiak \& A.Smirnov (1998). AERONET - A federated instrument network and data archive for aerosol characterization, Rem.Sens.Env., 66 (1), pp 1-16

Holben, B.N., Tanre, D., Smirnov, A., Eck, T.F., Slutsker, I., Abuhassan, N., Newcomb, W.W., Schafer, J., Chatenet, B., Lavenue, F., Kaufman, Y.J., Castle, J.V., Setzer, A., Markham, B., Clark, D., Frouin, R., Halthore, R., Karnieli, A., O'Neill, N.T., Pietras, C., Pinker, R.T., Voss, K. \& G. Zibordi (2001). An emerging ground-based aerosol climatology: Aerosol Optical Depth from AERONET, J. Geophys. Res., 106, pp. 12 067-12 097

Hofmann-Wellenhof, B., H. Lichtenegger \& E. Wasle (2008). GNSS - Global Navigation Satellite Systems GPS, GLONASS, Galileo, and more. Springer Wien NewYork

Kruczyk, M. (2012). IGS Tropospheric Products - Quality Verification and Assessment of Usefulness in Climatology, International GNSS Service Workshop Symposium, 23 - 27 July 2012, Olsztyn, Poland, poster: P06-09

Kruczyk, M. (2013). Opóźnienie troposferyczne GNSS i jego zastosowanie do badań stanu atmosfery. Wydawnictwo Politechniki Warszawskiej, seria Prace naukowe Geodezja i Kartografia, nr 54, Warszawa 2013

Kruczyk, M. (2014). Long Series of GNSS Integrated Precipitable Water as a Climate Change Indicator, Reports on Geodesy and Geoinformatics, Vol. 99 (2015) ss. 118; DOI:10.2478/rgg-2015-0008 
Kruczyk, M. (2015). Comparison of Techniques for Integrated Precipitable Water Measurement in Polar Region, Geoinformation Issues Vol. 7, No 1(7)/ 2015 pp. $15-29$

Kruczyk, M. \& Liwosz, T. (2012). Tropospheric Delay from EPN Reprocessing by WUT LAC as Valuable Data Source - in Comparison to Operational EPN Products and Aerological Data, Reports on Geodesy, No 1 (92)/2012, pp 105-118.

Kruczyk, M. \& Liwosz, T. (2015). Integrated precipitable water vapour measurements at Polish Polar Station Hornsund from GPS observations verified by aerological techniques, Reports on Geodesy and Geoinformatics, Vol 98 (2015) 1-17; DOI: 10.2478/rgg-2015-0001

Kruczyk, M., Liwosz, T. \& Rogowski, J. (2011). IPW from various sources: GPS tropospheric solution, sunphotometer, radiosounding and numerical weather prediction model - conformity analysis. Geophysical Research Abstracts Vol. 13, EGU2011-12348, EGU General Assembly 2011

Liwosz, T., Kruczyk M. \& Rogowski J. (2010). WUT LAC Report. Paper presented at 7th EUREF LAC EUREF Analysis Workshop, Warsaw, November 18-19 2010 (http://www.epncb.oma.be/ newsmails/workshops/EPNLACWS 2010/day1/s2/8 wut lac report.pdf)

Van Malderen, R., Brenot, H., Pottiaux, E., Beirle, S., Hermans, C., De Mazière, M., Wagner, T., De Backer, H. \& Bruyninx, C. (2014). A multi-site techniques intercomparison of integrated water vapour observations for climate change analysis. Atmospheric Measurement Techniques Discussions, Volume 7, Issue 2, 2014, pp 1075-1151

Mcllven, R. (2010). Fundamentals of Weather and Climate, Second Edition, Oxford University Press

Munch, S.W. (2014). Atmospheric Water Vapour Sensing by Means of Differential Absorption Spectrometry Using Solar and Lunar Radiation, Geodätischgeophysikalische Arbeiten in der Schweitz, Volume 92

Pacione, R., Pace B., de Haan S.; Vedel H., Lanotte R. \& Vespe F. (2011). Combination Methods of Tropospheric Time Series, Adv. Space Res., 47(2), pp 323-335, DOI: 10.1016/j.asr.2010.07.021

Pérez-Ramírez, D., Whiteman, D.N., Smirnov, A., Lyamani, H., Holben, B., Pinker, R., Andrade, M. \& Alados-Arboledas, L. (2014). Evaluation of AERONET precipitable water vapor versus microwave radiometry, GPS and radiosondes at ARM sites, J. Geophys. Res. - Atmos., 119, DOI:10.1002/ 2014JD021730

Platt, U. (1994). Differential optical absorption spectroscopy (DOAS), Chem. Anal. Series, 127 , pp $27-83$

Querel, R. \& Naylor D. (2011). Lunar absorption spectrophotometer for measuring atmospheric water vapour, Applied Optics Vol. 50, No. 4 pp 447-453

Rocken, C., Ware, R., Van Hove, T., Solheim, F., Alber, C., Johnson, J., Bevis, M. \& Businger, S. (1993). Sensing atmospheric water vapor with the Global Positioning System. Geophys. Res. Lett., 20, 2631

Saastamoinen, J. (1972). Atmospheric Correction for the troposphere and stratosphere in radio ranging of satellites. The Use of Artificial Satellites for Geodesy Geophysics Monograph Series, S. W. Henriksen et al., Ed., pp 247-251

Salby M.L., (2012). Physics of the Atmosphere and Climate, Cambridge University Press.

Schmid, B. et al. (2001). Comparison of columnar water-vapour measurements from solar transmittance methods, Applied Optics Vol. 40, No. 12 pp 1886-1896 
Shelton, M.L., (2009). Hydrometeorology. Perspectives and Applications, Cambridge University Press.

Vedel, H., Mogensen, K.S. \& X.-Y. Huang (2001). Calculation of zenith delays from meteorological data, comparison of NWP model, radiosonde and GPS delays, Phys. Chem. Earth, Vol. 26, No 6-8, pp. 497-502.

EPN WUT LAC log file: http://www.epncb.oma.be/ftp/center/analysis/WUT.LAC

TU Wien mean temperature data: http://ggosatm.hg.tuwien.ac.at/DELAY/ETC/TMEAN

VMF1: http://www.iers.org/IERS/EN/Publications/TechnicalNotes/tn36.html

\section{Author:}

Dr Michał Kruczyk 1), kruczyk@gik.pw.edu.pl

Dr Tomasz Liwosz 1), tl@gik.pw.edu.pl

Dr Aleksander Pietruczuk 2), alek@igf.edu.pl

1) Department of Geodesy and Geodetic Astronomy, Faculty of Geodesy and Cartography, Warsaw University of Technology,

PI. Politechniki 1, 00-661, Warsaw, Poland

2) Institute of Geophysics, Polish Academy of Sciences,

ul. Księcia Janusza 64, 01-452 Warsaw, Poland 